Indigenous peoples in Canada/Australia with those in, say, African nations where they are the majority and even in control of the state. Although it is emotionally appealing to refer to Aboriginal peoples as living in Third World conditions, the comparison is debatable. Young fails to comprehend the impact of state-supported programs such as medicare, education allowances, and housing. Few Aboriginal people in Canada, at least, die of protein/calorie malnutrition, in contrast to many areas of Africa. These are not petty differences, and they require considerably more thought than has been applied here. So, whereas the comparison works on one level, theoretically the volume is lacking. This should not deter those interested in international development issues, however, for the author has done a credible job researching and collating a large amount of information on the two countries. Comparisons such as we have here serve to advance our understanding of the effects of globalization on the world's Indigenous peoples.

\title{
Folk Management in the World's Fisheries: Lessons for Modern Fisheries Management, Christopher L. Dyer and James R. McGoodwin, editors. 1994. Niwot, CO: University Press of Colorado. xiv, 339
}

\section{pp.}

\author{
Reviewed by Patricia M. Clay, National Marine Fisheries Service, \\ Woods Hole, MA
}

This is a well-written book that addresses two questions currently debated hotly in fishery management circles: How do we address the worldwide decline in fishery resources? and To what extent can and should fisherfolk have a significant voice in the management process?

Offered as one possible response to both is the concept of "folk management." Folk management, as defined by this volume's editors, is related to such terms as "indigenous management," "community-based management," and "bottom-up management." Whereas these other terms are often primarily based on the management of space (that is, systems of tenure), Dyer and McGoodwin regard folk management as more broadly encompassing, also including effort limitation and stock productivity enhancement. Folk management is part of a people's fishing "technology," broadly construed, and includes an ideational component.

This volume seeks to document cases of folk management worldwide, to analyze the components of their success or failure, and to offer these insights to modern fishery managers in hopes of contributing to a more collaborative form of fisheries management-what has been described in much recent literature and some of the case studies in this volume as "co-management." Case studies are presented primarily from the Americas, but touching on several continents and including diverse fishing regimes. Pomeroy writes about institutional arrangements across multiple jurisdictions in the highland Lake Chapala district of Mexico, whereas McGoodwin presents another Mexican case from the rural Pacific coast. Cases presented by Palmer and Felt are from the North Atlantic, 
whereas Gill examines Alaskan salmon fisheries in the wake of the Exxon Valdez oil spill. Fisheries on the U.S. Gulf Coast are the subject of discussions by Dyer and Leard and by Ward and Weeks. Stoffle et al. examine artisanal fishing in the Dominican Republic. Jentoft and Mikalsen describe fjord fishing in coastal Norway, whereas cases presented by Ruddle and Anderson are from Southeast Asia and China, respectively. Though an additional Asian or European case study would have improved the volume's geographic coverage, the examples cover a broad range of system types and theoretical perspectives, drawing on references as varied as Elinor Ostrom, Roy Rappaport, and Mary Douglas.

One especially useful feature is the "Lessons for Modern Fisheries Management" section at the end of each chapter. This section summarizes the key points as numbered bullets--a sort of "Executive Summary." My only quibble with these "Lessons" is that they include little contextual or ethnographic data. If the idea is to give managers the option of reading only these portions, then the proposed goal of "knowing more about folk management" is only partially achieved. This caveat is tempered, however, by acknowledging the need for generalizations and overarching theory to be making sense of the recent profusion of case studies. Both the "Lessons" and Pinkerton's "Summary and Conclusions" chapter address that need.

In that vein, Pinkerton asks two questions: "What are the minimum conditions under which one could expect folk management or co-management to arise?" and "What are the main vulnerabilities of a co-management or folk management system to be undermined?" Using the ethnographic case studies in the volume and recent theory on institution building and resource management, she then formulates 20 testable hypotheses, and summarizes the policy lessons and implications overall. This poses a challenge to other social science fisheries researchers. By seeking to test her hypotheses, we can advance the current state of theory. This is an area where anthropologists in particular must make improvements: if anthropological insights are to be accepted in management and policymaking, they must include clearly testable predictions of behavior.

In fact, anthropologists and related social scientists have only recently begun to be included in many nations' fishery management institutions, and their potential contributions are often little understood. Although one case study (Ward and Weeks) specifically addresses the interactions of managers (primarily field biologists) and fisherfolk, it would have been useful to also see more discussion of how better to articulate the interdependent roles of biologists and social scientists. In the "Introduction," the editors state that fisheries management must address both resource conservation and allocation. They further add: "Obviously, the first problem is mainly one for marine biologists." Given that the conservation and allocation dimensions are inextricably linked in most of the volume's case studies, this statement seems to be as much an attempt to calm biologists' fears as a statement of appropriate division of labor and collaborative effort. Perhaps "collaboration" is the subject for another volume.

Minor caveats aside, overall the book is a welcome addition to the literature on comanagement and common property resources. Aimed at both social scientists and fisheries managers with marine biology backgrounds, it manages to combine sound fisheries and social science without being so technical that it excludes the nonspecialist.

\section{Weaving Identities: Construction of Dress and Self in a Highland Guatemalan Town, by Carol}

